\title{
Involvement of the Secretory Pathway for AMPA Receptors in NMDA-Induced Potentiation in Hippocampus
}

\author{
Greg Broutman and Michel Baudry \\ Neuroscience Program, University of Southern California, Los Angeles, California 90089-2520
}

\begin{abstract}
A chemical form of synaptic potentiation was produced with a brief bath application of NMDA to rat hippocampal slices. Two methods were used to assess changes in membrane-bound AMPA receptors. Traditional subcellular fractionation was used to isolate synaptic membranes; alternatively, membrane receptors were cross-linked with the membrane-impermeable reagent bis(sulfosuccinimidyl) suberate, and levels of nonmembrane receptors were determined. In both cases, Western blots were used to determine the content of receptor subunits in various subcellular fractions. NMDA-induced potentiation was associated with increased levels of glutamate receptor 1 (GluR1) and GluR2/3 subunits of AMPA receptors in synaptic membrane preparations, whereas no change was observed in whole homogenates. Both $\mathrm{KN}-62$, an inhibitor of calcium/cal-
\end{abstract}

modulin kinase, and calpain inhibitor III, a calpain inhibitor, inhibited NMDA-induced potentiation and changes in GluR1 and GluR2/3 subunits of AMPA receptors. Brefeldin A (BFA) inhibits protein trafficking between the Golgi apparatus and cell membranes. Pretreatment of hippocampal slices with BFA significantly decreased NMDA-induced potentiation and completely prevented an NMDA-induced increase in GluR1 levels in membrane fractions. Thus, the levels of GluR1 and GluR2/3 subunits of AMPA receptors are rapidly upregulated in synaptic membranes under conditions associated with potentiation of synaptic responses, and this upregulation requires a functional secretory pathway.

Key words: AMPA receptors; brefeldin A; exocytosis; longterm potentiation; Golgi; hippocampal slice
Since its discovery nearly 30 years ago (Bliss and Lomo, 1973), long-term potentiation (LTP) has been heralded as a cellular mechanism for memory formation. The detailed cellular and molecular mechanisms that underlie this phenomenon remain a hotly debated issue. Our laboratory has proposed that LTP could occur because of modifications of AMPA receptors (Bi et al., 1998). This hypothesis was first based on the existence of a calcium-dependent upregulation of glutamate binding in synaptic membranes (Lynch and Baudry, 1984). It was later found that the binding and electrophysiological properties of one subtype of glutamate receptors, the AMPA receptors, were indeed modified as a result of LTP (Staubli et al., 1992; Maren et al., 1993; Kolta et al., 1998). Lynch and colleagues argued for an increase in the kinetics of the receptor-associated ion channel (Ambros-Ingerson and Lynch, 1993; Ambros-Ingerson et al., 1993), whereas Berger and colleagues proposed a redistribution of existing receptors within the postsynaptic density (Xie et al., 1997). Alternatively, translocation of receptors from an intracellular pool to synaptic membranes could result in increased functional AMPA receptors (Standley et al., 1996).

Other lines of investigation have led to the notion of silent synapses, synapses with functional NMDA receptors but lacking functional AMPA receptors (Isaac et al., 1995, 1996, 1999; Liao et al., 1995). After LTP induction, such synapses would become activated because of the "unmasking" of functional AMPA receptors. Both the distribution of AMPA receptors and the morphology of synaptic contacts are regulated by synaptic activity

Received Aug. 18, 2000; revised Oct. 9, 2000; accepted Oct. 12, 2000.

The research was supported by Grant AG14751 from the National Institute on Aging (principal investigator C. E. Finch). We thank Dr. S. Standley (currently at the National Institutes of Health) for helpful discussions at the origin of this work.

Correspondence should be addressed to Michel Baudry, HNB 124, University of Southern California, Los Angeles, CA 90089-2520. E-mail: baudry@neuro.usc.edu. Copyright (C) 2001 Society for Neuroscience $0270-6474 / 01 / 210027-08 \$ 15.00 / 0$
(Engert and Bonhoeffer, 1999; Maletic-Savatic et al., 1999; Toni et al., 1999), and a rapid cycling of AMPA receptors in and out of synaptic membranes has been documented (Song et al., 1998; Carroll et al., 1999; Luscher et al., 1999; Noel et al., 1999; Shi et al., 1999).

Several methods have been used to produce widespread LTP or long-term depression (LTD) by chemical instead of electrical stimulation. A brief application of a high glycine concentration produced a long-lasting potentiation that shared mechanisms similar to those observed for tetanus-induced potentiation (Shahi et al., 1993; Musleh et al., 1997). A mixture of NMDA, glycine, and spermine elicited an LTP-like increase in synaptic transmission (Thibault et al., 1989), whereas a brief NMDA application induced LTD in CA1 (Lee et al., 1998). In the present study, we used a brief application of NMDA in hippocampal slices to produce a long-lasting increase in synaptic transmission and to determine changes in AMPA receptor subunits in various subcellular fractions and possible mechanisms underlying such changes. In particular, we tested the effects of the drug brefeldin A (BFA) on NMDA-induced potentiation and changes in synaptic AMPA receptors. BFA is a fungal metabolite that causes the Golgi membrane to fuse with the endoplasmic reticulum (ER), thereby inhibiting exocytosis of newly synthesized proteins (Misumi et al., 1986; Oda et al., 1987; Klausner et al., 1992). Our results indicate that AMPA receptors are inserted from an intracellular pool into synaptic membranes under conditions associated with LTP-like increased synaptic transmission and that a functional secretory pathway is required for this process.

\section{MATERIALS AND METHODS}

Electrophysiology in hippocampal slices. Transverse hippocampal slices (400 $\mu \mathrm{m}$ thick) were prepared from adult (3- to 4-month-old) Sprague Dawley rats using a McIlwain tissue chopper. Slices were immediately placed in ice-cold cutting buffer containing (in mM): $124 \mathrm{NaCl}, 3 \mathrm{KCl}$, 

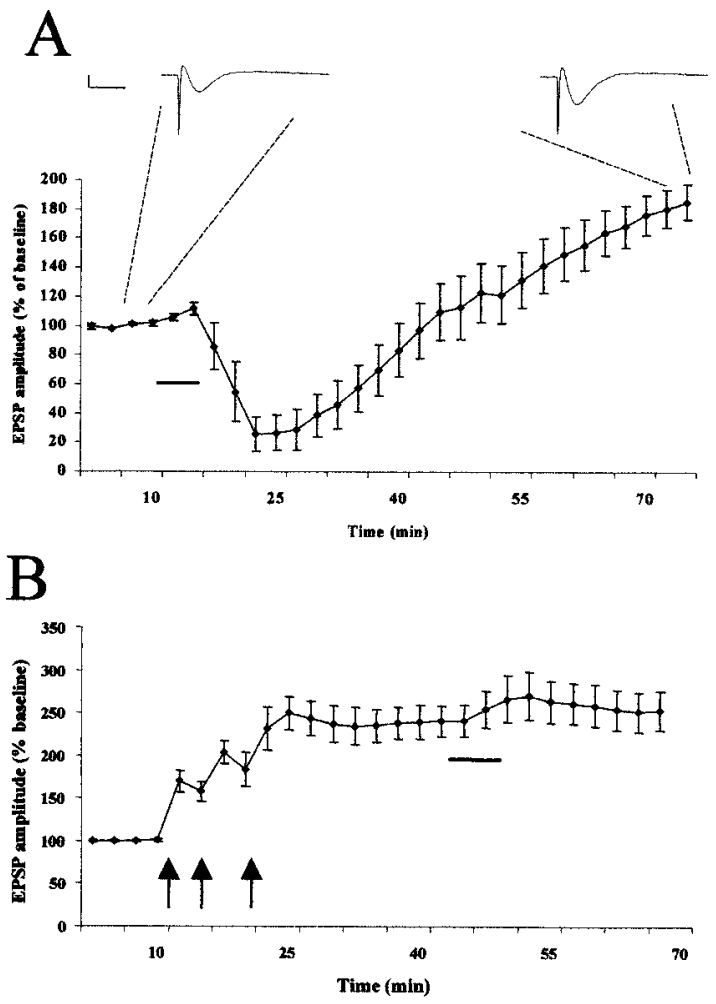

Figure 1. NMDA-induced potentiation in rat hippocampal slices. Hippocampal slices were prepared as described in Materials and Methods. Stimulating and recording electrodes were positioned in CA1. After a 10 min baseline recording, either $50 \mu \mathrm{M}$ NMDA was perfused for 5 min (bar; $A$ ) or three high-frequency stimulation bursts (arrows) were given $(B)$, separated by $5 \mathrm{~min}$. Twenty minutes after the last high-frequency stimulation burst, $50 \mu \mathrm{M}$ NMDA was perfused for $5 \mathrm{~min}$. Results represent the amplitudes of evoked responses and are expressed as percentage of responses averaged over the $10 \mathrm{~min}$ baseline period. They are means \pm SEM of eight and seven experiments, respectively. Insets are traces (averages of 5 successive responses) from representative experiments at the indicated times. Calibration: $1 \mathrm{mV}, 10 \mathrm{msec}$.

$1.25 \mathrm{KH}_{2} \mathrm{PO} 4,1 \mathrm{CaCl}_{2}, 3 \mathrm{MgCl}_{2}, 26 \mathrm{NaHCO}_{3}, 10$ glucose, and 2 L-ascorbate, and saturated with $95 \% \mathrm{O}_{2}-5 \% \mathrm{CO}_{2}$. Slices then had the $\mathrm{CA} 3$ region removed with a razor blade before being transferred to an interface chamber. Slices were maintained at $32^{\circ} \mathrm{C}$ and constantly perfused with an artificial CSF (ACSF) containing (in $\mathrm{mM}$ ): $124 \mathrm{NaCl}, 3$ $\mathrm{KCl}, 1.25 \mathrm{KH}_{2} \mathrm{PO} 4,3 \mathrm{CaCl}_{2}, 1 \mathrm{MgCl}_{2}, 26 \mathrm{NaHCO}_{3}, 10$ glucose, and 2 L-ascorbate; in addition, they were constantly oxygenated with a $95 \%$ $\mathrm{O}_{2}-5 \% \mathrm{CO}_{2}$ mixture at a rate of $1 \mathrm{ml} / \mathrm{min}$. Extracellular field recordings were obtained in CA1 using a bipolar stimulating electrode and a glass recording electrode (containing $2 \mathrm{M} \mathrm{NaCl}$ ) placed in stratum radiatum. Stimulus intensity was set to approximately one-third of the intensity required to evoke a population spike, and responses were evoked every $30 \mathrm{sec}(0.033 \mathrm{~Hz}$, pulse duration of $0.1 \mathrm{msec})$. All drugs were perfused in ACSF.

NMDA treatment of hippocampal slices. Hippocampal slices were prepared and placed in an interface chamber as described above (electrophysiology). After a $1 \mathrm{hr}$ equilibration period, slices were treated with 50 $\mu \mathrm{M}$ NMDA for $5 \mathrm{~min}$. Generally, three slices were treated per group so as to obtain enough tissue for Western blots. Slices were collected $15 \mathrm{~min}$ and, where indicated, $1 \mathrm{hr}$ after the end of the NMDA treatment and placed in ice-cold sucrose solution containing $0.32 \mathrm{M}$ sucrose, $10 \mathrm{~mm}$ EDTA, and $10 \mu \mathrm{M}$ leupeptin (homogenization solution). Slices were then stored at $-70^{\circ} \mathrm{C}$ for later use (i.e., preparation of membranes and Western blots).

Membrane preparation. Crude synaptic membranes were prepared from hippocampal slices by homogenizing them by sonication in the homogenization solution. Aliquots of the homogenates were processed for Western blots. The rest of the homogenate was then centrifuged at $24,000 \times g$ at $4^{\circ} \mathrm{C}$ for $20 \mathrm{~min}$. The supernatant was discarded, and the pellet was resuspended in distilled water containing $100 \mu \mathrm{M}$ EGTA. Samples were then centrifuged again as described above, and the supernatant was again discarded. The pellet was resuspended in Tris-acetate buffer (100 mM, pH 7.4) containing $100 \mu \mathrm{M}$ EGTA and centrifuged as described above. This last centrif ugation step was repeated, and the final pellet was resuspended in ice-cold Tris-acetate buffer and immediately used for Western blots.

Cross-linking of membrane proteins. Control or NMDA-treated slices were collected and treated with the cross-linker agent bis(sulfosuccinimidyl) suberate $\left(\mathrm{BS}^{3}\right)$ as described previously by Hall et al. (1997). Briefly, slices were first washed twice in saline solution (SS) containing (in mM): $137 \mathrm{NaCl}, 5.3 \mathrm{KCl}, 170 \mathrm{Na}_{2} \mathrm{HPO}_{4}, 220 \mathrm{KH}_{2} \mathrm{PO}_{4}, 10 \mathrm{HEPES}, 33$ glucose, and 44 sucrose, $\mathrm{pH}$ 7.3. One-half of the slices were kept in SS, and the other half were placed in SS containing $1 \mathrm{mg} / \mathrm{ml} \mathrm{BS}^{3}$ [a concentration sufficient to saturate all of the cross-linking sites and to leave intracellular proteins intact (Hall et al., 1997)] and incubated for $30 \mathrm{~min}$ at $37^{\circ} \mathrm{C}$ with agitation. After the incubation, slices were washed three times in harvest buffer [a modified SS additionally containing (in mM): 1 EDTA, 1 PMSF, and 50 ethanolamine]. Slices were then saved in harvest buffer and frozen at $-70^{\circ} \mathrm{C}$ until they were used for Western blots.

Western blots. Samples were thawed on ice, and slices used in crosslinking studies were homogenized by sonication. Protein assays were performed using the Bio-Rad protein assay (Bio-Rad, Hercules, CA) to determine protein concentration. Equal volumes of $2 \times$ sample buffer (2\% SDS, $50 \mathrm{~mm}$ Tris-HCl, $\mathrm{pH} 6.8,10 \%$ 2-mercaptoethanol, $10 \%$ glycerol, and $0.1 \%$ bromophenol blue) were added to samples of either whole homogenates or synaptic membranes, and samples were boiled for 10 min. Aliquots containing equal amounts of proteins were run on SDSpolyacrylamide gels containing $8 \%$ polyacrylamide, and proteins were transferred onto nitrocellulose membranes. The membranes were incubated in Tris-buffered saline (TBS) containing 3\% gelatin for $1 \mathrm{hr}$ at room temperature before an overnight incubation with primary antibodies in TBS containing $1 \%$ gelatin and $0.05 \%$ Tween 20. Glutamate receptor 1 (GluR1) and GluR2/3 antibodies were obtained from Chemicon (Temecula, CA) (1:2000 dilution). Immunostaining was detected by
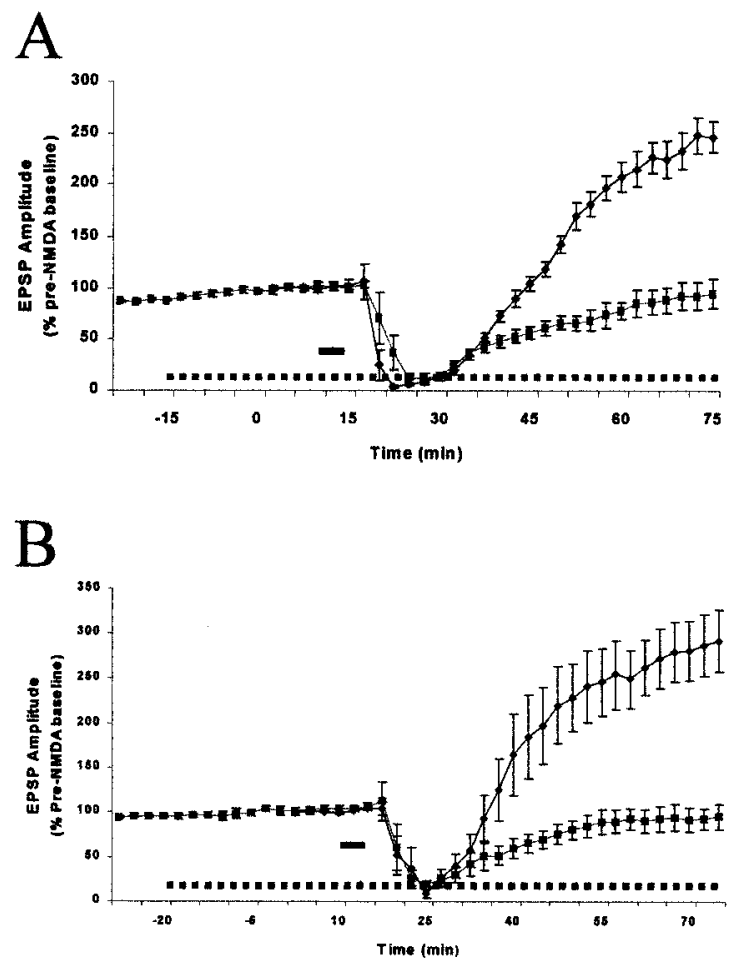

Figure 2. Effects of inhibitors of both calpain and CamKII on NMDALTP. Hippocampal slices were preincubated with either $10 \mu \mathrm{M}$ CalI III $(A)$ or $2 \mu \mathrm{M} \mathrm{KN}-62$ (B; dotted line) before application of $50 \mu \mathrm{M}$ NMDA (solid bar). Results represent the amplitudes of evoked responses and are expressed as percentage of the average baseline responses recorded over $10 \mathrm{~min}$ before NMDA application. They are means \pm SEM of six and seven experiments, respectively. 
A

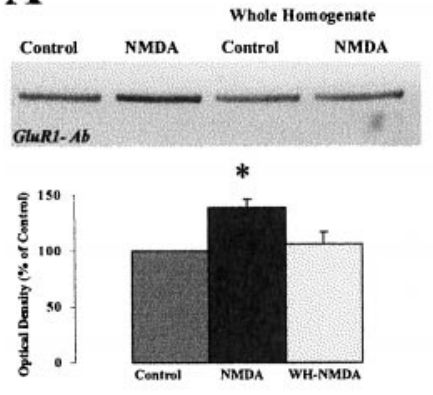

B
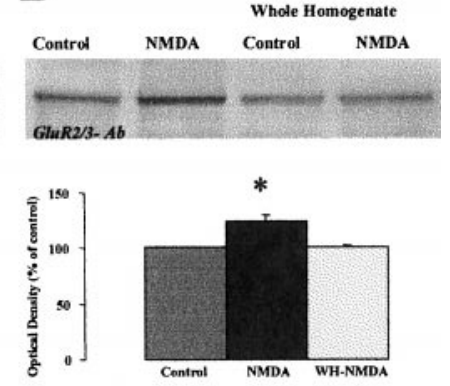

tetanus-induced LTP (del Cerro et al., 1990; Denny et al., 1990; Vanderklish et al., 1995). Slices treated with NMDA were processed for immunoblotting with spectrin antibodies, and the levels of the $150 \mathrm{kDa}$ breakdown product generated by calpainmediated degradation of spectrin were quantified. NMDA treatment resulted in a significant $(41 \pm 6 \% ; n=8 ; p<0.001$; Student's $t$ test) increase in this breakdown product, an effect that was blocked by preincubating slices with calpain inhibitor III (CalI III), a membrane-permeable inhibitor of calpain $(5 \pm 8 \%)$ (data not shown). We also tested the effects of CalI III on NMDA-LTP. Slices were preincubated with CalI III before

Figure 3. Changes in synaptic AMPA but not NMDA receptor subunits with NMDA-LTP. Hippocampal slices were treated with $50 \mu \mathrm{M}$ NMDA for $5 \mathrm{~min}$ and were collected $15 \mathrm{~min}$ after the end of NMDA treatment. Synaptic membranes were prepared, and aliquots of whole homogenates and membranes were processed for immunoblots with antibodies recognizing either the GluR1 and GluR2/3 subunits of AMPA receptors $(A, B$, respectively) or the NR1 subunits of the NMDA receptor $(C)$. Top panels, Representative Western blots. Bottom panels, Quantification of Western blots similar to those shown in top panels. Results represent optical density, are expressed as percentage of values measured in samples from control slices, and are means \pm SEM of 15 (GluR1), 7 (GluR2/3), and 4 (NR1) experiments. ${ }^{*} p<0.01$; Student's $t$ test.

incubating with an alkaline phosphatase-conjugated secondary antibody (Bio-Rad) also in TBS containing $1 \%$ gelatin and $0.05 \%$ Tween 20 for 2 hr. Quantification of blots was done using ImageQuant software (Molecular Dynamics, Sunnyvale, CA).

\section{RESULTS}

\section{NMDA application induces a long-lasting increase in synaptic transmission in CA1}

Perfusion of hippocampal slices with $50 \mu \mathrm{M}$ NMDA for $5 \mathrm{~min}$ induced repeated bursts of high-frequency activity throughout the slices within 2-3 min after the end of perfusion. The CA3 region was therefore removed to minimize this NMDA-induced epileptiform activity. NMDA treatment also caused a rapid loss of EPSPs evoked in CA1 stratum radiatum by stimulation of the Schaffer collateral pathway. This loss of EPSP is attributed to NMDA-induced depolarization of CA1 pyramidal neurons and thus to a loss of driving force, an effect also seen with a similar protocol used to induce LTD in slices prepared from juvenile animals (Lee et al., 1998). After NMDA washout, EPSPs not only recovered but exhibited a large increase in amplitude compared with baseline values (Fig. 1). By $1 \mathrm{hr}$ after NMDA treatment, EPSP amplitudes had increased by $\sim 86 \pm 12 \%(n=8)$ above baseline values. This level of potentiation remained constant for at least $3 \mathrm{hr}$ after NMDA treatment, and this phenomenon is hereafter referred to as NMDA-LTP.

Several experiments were performed to compare NMDA-LTP with traditional tetanus-induced LTP. We first determined whether calpain was activated in NMDA-LTP as in the case of
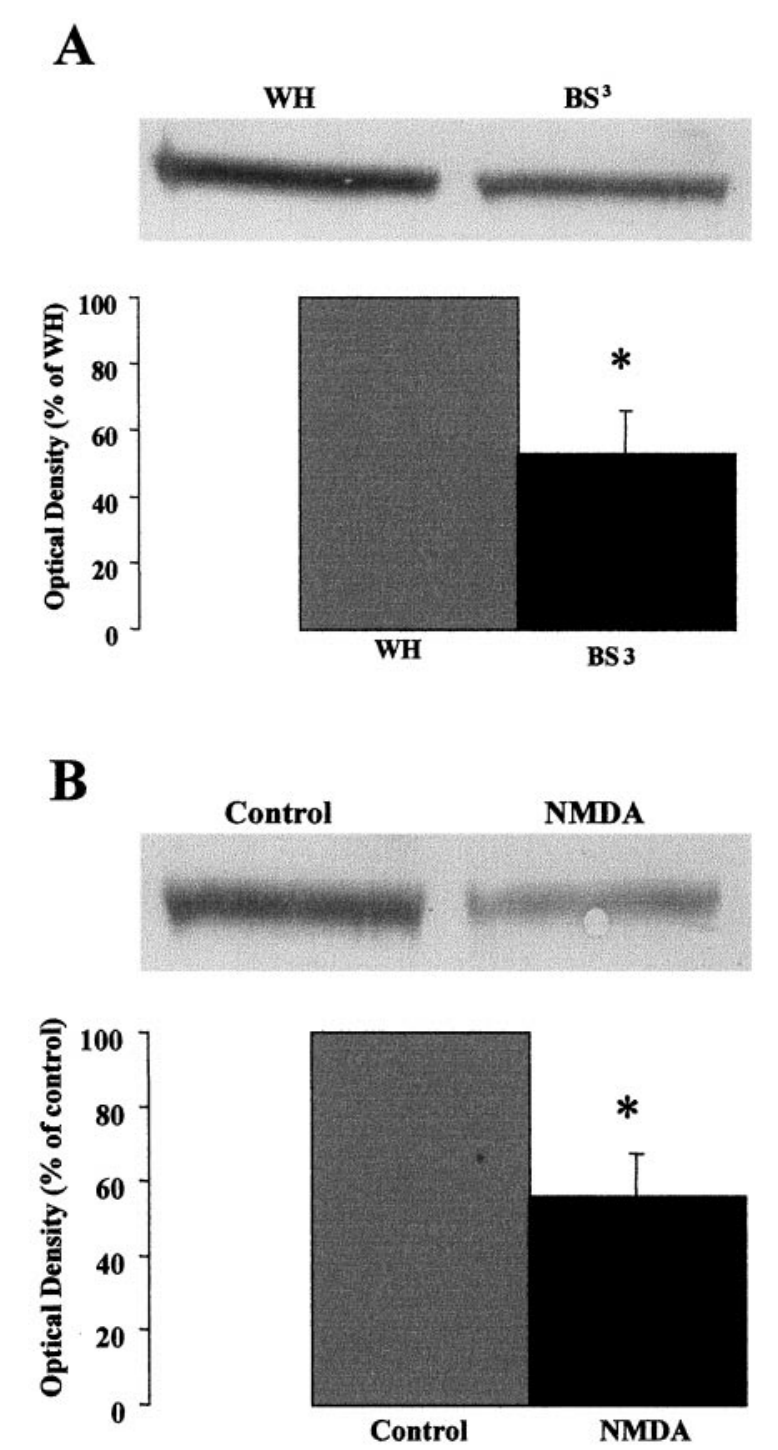

Figure 4. Changes in nonplasma membrane AMPA receptors with NMDA-LTP. Hippocampal slices were prepared as described in Materials and Methods. They were then treated with or without $\mathrm{BS}^{3}$ to determine the levels of intracellular AMPA receptor subunits (GluR1) with Western blots of aliquots from whole homogenates $(W H)$. Top panels, Representative blots. Bottom panels, Quantitative analysis of blots similar to those shown in top panels. $A$, Effects of $\mathrm{BS}^{3}$ in control slices. Homogenates were prepared from slices incubated in the absence $(W H)$ or presence $\left(B S^{3}\right)$ of $\mathrm{BS}^{3}$ and processed for immunoblots with GluR1 antibodies. $B$, Effects of $\mathrm{BS}^{3}$ in slices treated with $(N M D A)$ or without (Control) $50 \mu \mathrm{M}$ NMDA for $5 \mathrm{~min}$. Results represent percentage of values measured in whole homogenate $(A)$ or control $(B)$ and are means \pm SEM of four experiments. ${ }^{*} p<0.05$; Student's $t$ test. 
A GluR1

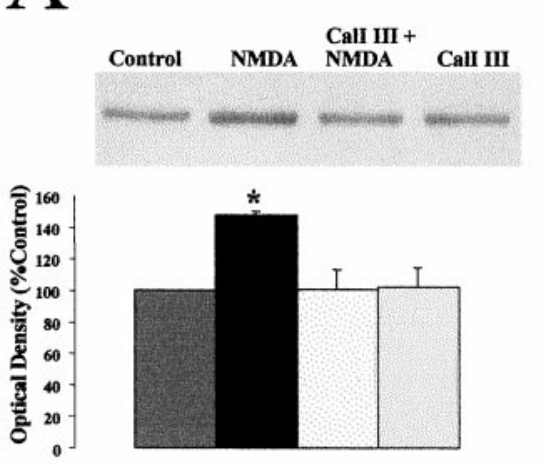

Figure 5. Effects of calpain and CamKII inhibitors on NMDA-induced changes in AMPA receptor subunits. Hippocampal slices were preincubated with either $10 \mu \mathrm{M}$ CalI III for $25 \min (A)$ or $2 \mu \mathrm{M} \mathrm{KN}-62$ for $30 \mathrm{~min}(B)$ before application of $50 \mu \mathrm{M}$ NMDA for $5 \mathrm{~min}$ and were collected $15 \mathrm{~min}$ after the end of NMDA treatment. Synaptic membranes were prepared, and aliquots of whole homogenates and membranes were processed for immunoblots with antibodies recognizing either the GluR1 or GluR2/3 subunits of AMPA receptors. Top panels, Representative Western blots. Bottom panels, Quantification of Western blots similar to those shown in top panels. Results represent optical density, are expressed as percentage of values measured in samples from control slices, and are means \pm SEM of four (GluR1) and four (GluR2/3) experiments for CalI III and six (GluR1) and four (GluR2/3) experiments for KN62. * $p<0.03$; Student's $t$ test.
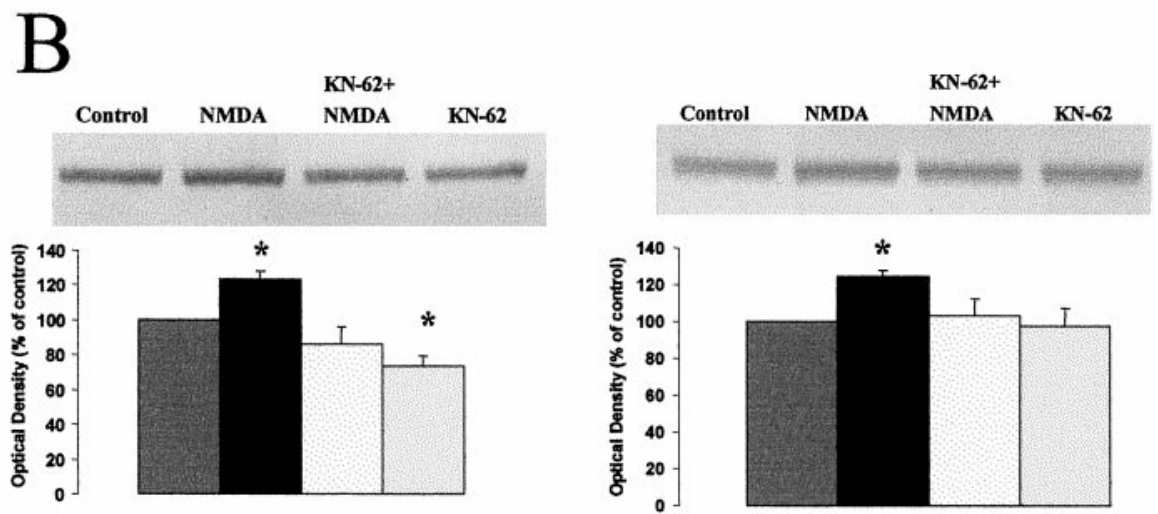

NMDA application. Treatment with CalI III caused a slight but significant increase in synaptic responses (Fig. 2A). Moreover, CalI III completely blocked NMDA-LTP $(-5 \pm 15$ vs $146 \pm$ $15 \% ; n=6 ; p<0.001$; Student's $t$ test) (Fig. $2 A$ ).

Several studies have indicated that calcium/calmodulin kinase type II (CamKII) plays a critical role in LTP (Malinow et al., 1989; Pettit et al., 1994; Lledo et al., 1995; Blitzer et al., 1998). Therefore, we determined the effects of KN-62, a CamKII inhibitor, on NMDA-LTP (Fig. 2B). KN-62 treatment had little effect on basal synaptic responses; however, after $1 \mathrm{hr}$, NMDA-induced potentiation was completely inhibited when compared with control slices $(-5 \pm 14$ vs $192 \pm 35 \%$, respectively; $n=7 ; p<0.001$; Student's $t$ test).

Finally, we also determined whether NMDA-LTP could be occluded by tetanus-induced LTP, a test that has been widely used to assess whether chemically induced LTP (or LTD) shares mechanisms similar to those observed for tetanus-induced LTP (or LTD). Tetanus-induced LTP was elicited by three episodes of high-frequency stimulation resulting in saturation of LTP (140 \pm $20 \% ; n=7)$. Under these conditions, NMDA application did not produce any further increase in synaptic responses (Fig. 1B).

\section{Changes in AMPA receptor distribution after NMDA-induced potentiation}

Potentiation was induced by NMDA treatment of hippocampal slices, and slices were collected 15 min after the end of NMDA treatment. Slices were then used to prepare crude synaptic membranes or were treated with $\mathrm{BS}^{3}$ to obtain an estimate of the levels of nonplasma membrane AMPA receptors.

\section{Synaptic membranes}

Slices were homogenized, and aliquots of the homogenates were used to prepare a crude synaptic membrane fraction. Western blots from homogenates and crude synaptic fractions were processed with antibodies against GluR1 or GluR2/3 subunits of AMPA receptors. NMDA treatment resulted in a significant increase in the abundance of both GluR1 $(+39 \pm 7 \% ; n=15 ; p<$ 0.01 ; Student's $t$ test) and GluR2/3 $(+24 \pm 6 \% ; n=6 ; p<0.01$; Student's $t$ test) subunits in synaptic membrane fractions (Fig. $3 A, B)$. A similar increase in GluR1 subunits was also present in slices collected $1 \mathrm{hr}$ after NMDA treatment (data not shown). However, there was no significant increase in GluR1 levels in homogenates of NMDA-treated slices at either time point $(+6 \pm$ $11 \% ; n=5)$.

As a control, we tested whether other synaptic proteins were upregulated by NMDA treatment. We determined the levels of NR1 subunits of NMDA receptors in the same fraction used to measure the levels of GluR1 subunits of AMPA receptors. NMDA treatment did not modify the levels of NR1 subunits in synaptic membranes when compared with levels found in membranes prepared from control slices $(+2 \pm 5 \% ; n=4)$ (Fig. $3 C)$.

\section{Cross-linking}

To confirm the results obtained with crude synaptic membrane fractions, we evaluated the levels of intracellular AMPA receptor subunits after NMDA treatment. The membrane-impermeable cross-linking reagent $\mathrm{BS}^{3}$ was used to effectively remove all surface receptors, as described previously by Hall et al. (1997). After $\mathrm{BS}^{3}$ treatment, slices were homogenized, and the number of non-cross-linked receptors (presumably representing intracellular receptors) was assessed with Western blots. As a control, whole homogenates of slices were incubated with $\mathrm{BS}^{3}$, and these samples showed little immunoreactivity when probed with GluR1 antibodies in Western blots (data not shown). This is presumably because most proteins in the homogenate are exposed to $\mathrm{BS}^{3}$ and 

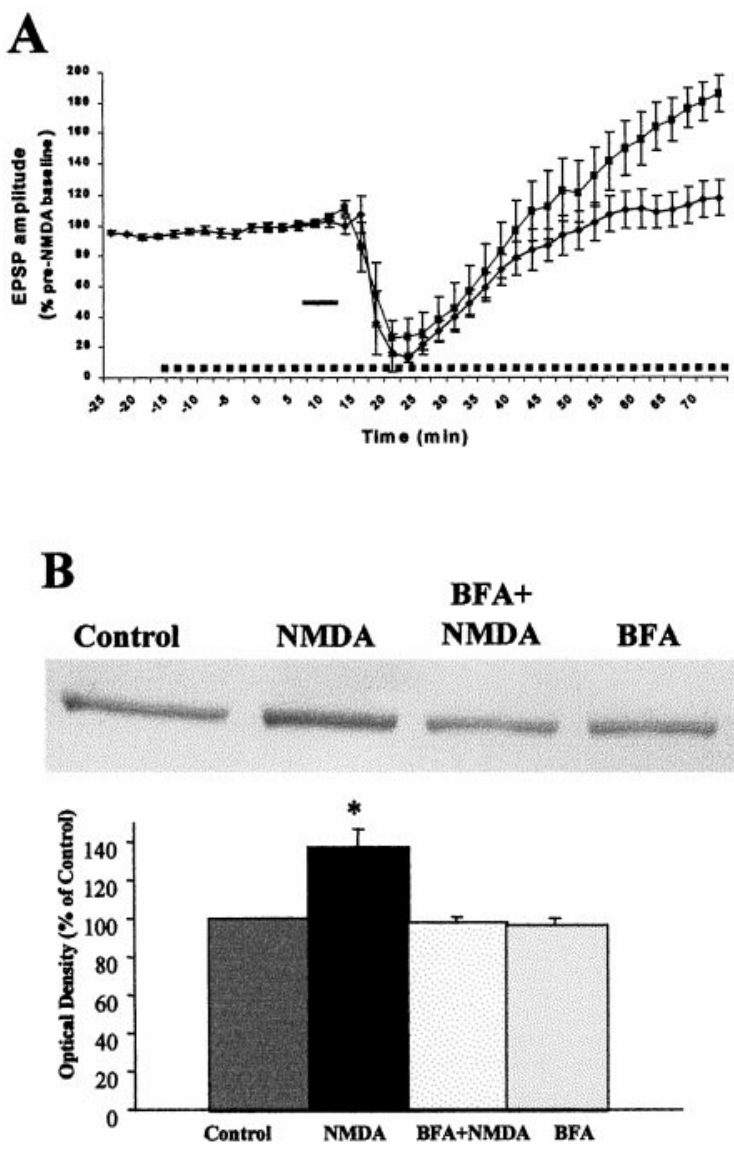

Figure 6. Effects of brefeldin A on NMDA-induced LTP and changes in GluR1 subunits. $A$, Hippocampal slices were prepared, and stimulating and recording electrodes were positioned in CA1. After a $10 \mathrm{~min}$ baseline period, BFA $(10 \mu \mathrm{g} / \mathrm{ml})$ was added to the perfusion medium (dotted line). Twenty-five minutes later, NMDA $(50 \mu \mathrm{M})$ was added for 5 min (solid bar). Amplitudes of EPSPs were measured, and values are expressed as percentage of the average values measured during the 10 min preceding NMDA application. Data are means \pm SEM of seven experiments. $B$, Hippocampal slices were incubated in the absence or presence of BFA. They were then treated with or without NMDA $(50 \mu \mathrm{M}, 5 \mathrm{~min})$. Fifteen minutes later, slices were collected, and synaptic membranes were prepared as described in Materials and Methods. Aliquots of membrane samples were processed for immunoblots with antibodies against GluR1 subunits of AMPA receptors. Top panel, Representative Western blots. Bottom panel, Quantification of Western blots similar to those shown in top panel. Results represent optical density of the GluR1-immunoreactive band and are expressed as percentage of values measured in control conditions (no BFA, no NMDA). Data are means \pm SEM of four experiments. ${ }^{*} p<0.02$; Student's $t$ test.

thus cross-linked, thereby forming large aggregates of proteins that do not penetrate polyacrylamide gels. Treatment of control slices with $\mathrm{BS}^{3}$ resulted in a $47 \pm 13 \%$ decrease in the levels of GluR1 compared with levels found in slices not treated with $\mathrm{BS}^{3}$ (Fig. $4 A$ ). This suggests that $\sim 53 \%$ of the total number of GluR1 subunits are located intracellularly under control conditions. After NMDA treatment, incubation with $\mathrm{BS}^{3}$ resulted in a $44 \pm$ $11 \%$ decrease in the levels of GluR1 subunits when compared with values found in control slices (Fig. 4B), indicating that there were significantly less intracellular receptors after NMDA treatment. When compared with whole homogenates from control slices, levels of GluR1 in NMDA-treated slices incubated with $\mathrm{BS}^{3}$ were decreased by $\sim 66 \%$, indicating that $\sim 66 \%$ of GluR1 subunits were membrane bound. Because levels of membrane- bound GluR1 subunits in control slices were $\sim 47 \%$ of total, this suggests that the number of membrane-bound receptor subunits increased by $\sim 40 \%$, a value in good agreement with that obtained with the subcellular fractionation approach.

\section{NMDA-induced changes in AMPA receptor distribution are calpain- and CamKII-dependent}

Because we observed that NMDA-LTP was blocked by inhibitors of calpain and CamKII, we determined whether these inhibitors could prevent NMDA-induced changes in AMPA receptor subunit distribution. Preincubation of slices with the calpain inhibitor CalI III completely blocked an NMDA-induced increase in the levels of GluR1 and GluR2/3 subunits (Fig. 5A). Preincubation of slices with the CamKII inhibitor KN-62 also completely inhibited an NMDA-induced increase in the levels of both GluR1 and GluR2/3 subunits of AMPA receptors in synaptic membranes (Fig. 5B). In Western blots using the GluR1 antibody, KN-62 alone caused a small yet significant decrease in immunoreactivity. However, this effect of $\mathrm{KN}-62$ was not significant in blots using the GluR2/3 antibody, although the same trend was seen.

\section{Brefeldin A inhibits NMDA-induced potentiation and changes in AMPA receptor subunits in membrane fractions}

Hippocampal slices were pretreated for 25 min with BFA before being subjected to NMDA treatment. BFA treatment had no effect on basal synaptic responses, but after $1 \mathrm{hr}$, NMDA-induced potentiation was almost completely inhibited when compared with control slices $[+18 \pm 12(n=8)$ vs $+86 \pm 12 \%(n=7)$, respectively; $p<0.02$; Student's $t$ test] (Fig. 6A). BFA treatment also completely inhibited an NMDA-induced increase in the levels of GluR1 subunits of AMPA receptors in synaptic membranes $(-2 \pm 3$ vs $+37 \pm 9 \%$, respectively; $n=4 ; p<0.02$; Student's $t$ test) (Fig. 6B).

\section{DISCUSSION}

Because only a small fraction of synapses are affected by the electrical stimulation protocols used to induce plasticity, chemical-pharmacological stimulation protocols have been developed to study biochemical changes associated with synaptic plasticity. Thus, several laboratories have used brief activation of NMDA receptors to produce widespread changes in synaptic efficacy in CA1 from hippocampal slices (Kauer et al., 1988; Thibault et al., 1989; Shahi et al., 1993; Lee et al., 1998). In our study, the application of $50 \mu \mathrm{M}$ NMDA for $5 \mathrm{~min}$ to hippocampal slices produced a long-lasting increase $(>3 \mathrm{hr})$ in synaptic efficacy. In addition, NMDA-induced increased synaptic transmission was associated with calpain activation as evidenced by increased formation of a calpain-mediated spectrin breakdown product and inhibition by a calpain inhibitor. It was also associated with the requirement for CamKII because it was blocked with an inhibitor of CamKII. Finally, NMDA-LTP was occluded by previous LTP saturation by tetanus-induced LTP. Thus, NMDA-LTP shares many features of tetanus-induced LTP, and it is reasonable to conclude that these two forms of potentiation share similar biochemical mechanisms. However, we cannot completely exclude the possibility that several consequences of NMDA application are not related to what happens in tetanus-induced LTP.

NMDA-LTP was associated with a rapid ( $<15 \mathrm{~min})$ and longlasting $(>1 \mathrm{hr})$ increase in the levels of synaptic AMPA receptor subunits. The decrease in synaptic responses observed at $15 \mathrm{~min}$ after NMDA treatment is likely because of the prolonged depolarization elicited by NMDA application that would mask any 

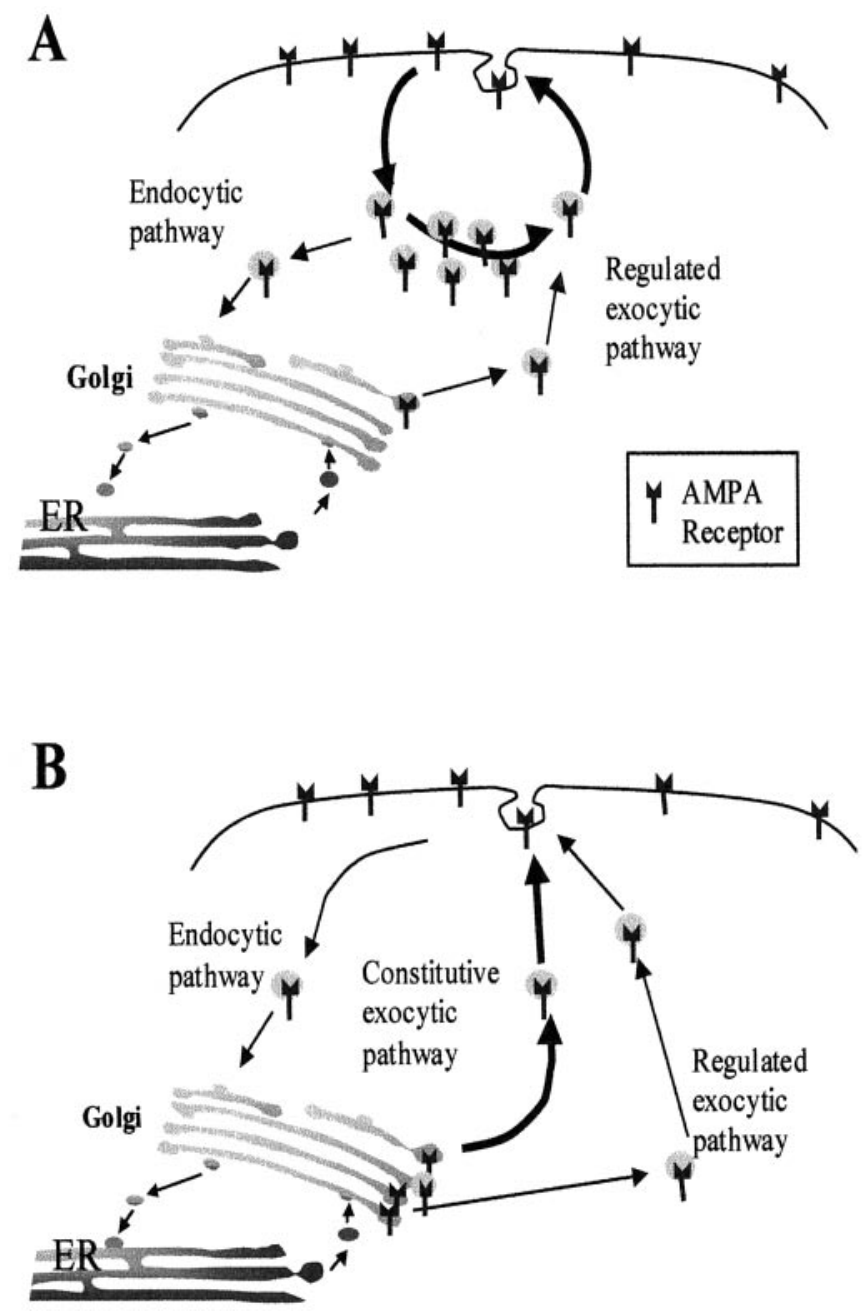

Figure 7. Postulated mechanisms for the involvement of the secretory pathway for AMPA receptors in LTP. A, A pool of subsynaptic receptors cycles in and out of the postsynaptic densities. After an LTP-inducing stimulus, a regulated exocytic pathway transports newly synthesized receptors from the Golgi apparatus to this pool. The resulting increase in the number of subsynaptic receptors would lead to an increase in the number of receptors to be inserted into the membrane. $B$, AMPA receptors cycle into and out of the synaptic membrane. This cycling of receptors involves a constitutively active as well as a regulated exocytic pathway, both of which involve Golgi-associated receptors. Under these conditions, the constitutive pathway would be involved in normal homeostatic regulation of the synaptic AMPA receptor population, whereas the regulated pathway would be involved in adding to the existing synaptic population only after LTP-inducing stimuli.

potentiation that could be present at this early time point. Because there was no change in receptor subunits in the homogenate, it is clear that the increase in synaptic AMPA receptors is independent of protein synthesis. Two potential mechanisms could account for such an upregulation of synaptic receptors: (1) a redistribution of existing membrane receptors to synaptic sites or (2) a translocation of intracellular receptors into synaptic membranes. Our results support the latter rather than the former mechanism. First, the observation of a decrease in the levels of GluR1 subunits in NMDA-treated slices versus control slices incubated with the cross-linking reagent $\mathrm{BS}^{3}$ is best explained by a decrease in the number of intracellular subunits. Second, BFA, which inhibits anterograde protein secretion from the Golgi, inhibited both NMDA-LTP and an NMDA-induced increase in synaptic AMPA receptor subunits. Therefore, NMDA-LTP is associated with upregulation of synaptic AMPA receptors, and this upregulation is likely because of the translocation of receptors from intracellular, Golgi-associated sites to synaptic sites.

Several data have indicated the existence of an intracellular pool of AMPA receptors (Baude et al., 1994, 1995; Henley, 1995; Standley et al., 1998; Rubio and Wenthold, 1999), although relatively little is known about these receptors, especially with regard to their function and location in dendritic and synaptic compartments. Based on biochemical studies, we proposed previously that these intracellular receptors represent unglycosylated, immature states of the receptors (Standley et al., 1998). The data obtained with $\mathrm{BS}^{3}$ also clearly support the existence of a relatively large pool of intracellular receptors, as shown previously in dissociated neurons (Hall et al., 1997). Recent evidence has suggested that AMPA receptors can rapidly cycle in and out of synaptic membranes and that this cycling is regulated by synaptic activity and could possibly be involved in synaptic plasticity (Luscher et al., 2000; Malinow et al., 2000; Turrigiano, 2000). In particular, infusion of botulinum toxin to prevent exocytosis resulted in a $30 \%$ decrease in AMPA receptor-mediated synaptic responses (Luscher et al., 1999). Because the same authors had previously observed a different result with intracellular infusion of botulinum toxin (Lledo et al., 1998), they proposed that this drug might have a different effect on regulated and constitutive exocytosis. Two recent studies have provided strong evidence for the involvement of a clathrin-dependent endocytotic process in LTD in hippocampus and cerebellum (Man et al., 2000; Wang and Linden, 2000). Our results provide some clues regarding the links between the secretory pathway and exocytosis and the involvement of these processes in LTP. The results obtained with BFA indicate that receptors originating in the ER-Golgi apparatus are critically involved in LTP but not in baseline responses. Two possible scenarios could account for these results (Fig. 7). In the first one, a subsynaptic pool of receptors could be located beneath synaptic membranes (Fig. 7A). Receptors from this pool could be rapidly inserted into the membrane, whereas membrane receptors could be endocytosed as a result of normal synaptic activity. The size of the membrane pool of receptors would be dependent on the size of the subsynaptic pool, as well as on the rates of receptor insertion and internalization. LTP would activate a regulated exocytic pathway, and receptors from the ER-Golgi complex would shuttle into the pool of cycling receptors. This would effectively increase the number of receptors inserted into the synapse. This hypothesis implies the existence of two distinct intracellular receptor populations, with one population associated with the Golgi and one (a subsynaptic population) that is independent of the Golgi. Alternatively, it is possible that all the intracellular receptors are associated with the ER-Golgi complex (Fig. $7 B$ ). In this case, there could be both a constitutive and a regulated exocytic pathway contributing to receptor insertion in synaptic membranes. The constitutive pathway could account for the normal maintenance of the synaptic receptor population, whereas the regulated pathway would be activated during LTP, thus adding to the constitutive pathway the number of receptors to be inserted into the synapse. Either scenario requires the existence of a regulated exocytic pathway and, as mentioned above, there is some evidence for such a pathway (Luscher et al., 1999). A recent study describes the existence of a calciumdependent dendritic exocytosis that is dependent on CamKII activity (Maletic-Savatic et al., 1998; Maletic-Savatic and Malinow, 1998). This could well be identical to the regulated exocytic 
pathway that is disrupted by BFA in our experiments. Interestingly, the delivery of AMPA receptors to the synapse also requires CamKII (Hayashi et al., 2000), a result in good agreement with our data with $\mathrm{KN}-62$. In addition, both scenarios require that the ER-Golgi complex be located fairly close to synaptic membranes. The notion that the spine apparatus represents an extension of the ER has been around for a long time (Harris and Stevens, 1988; Martone et al., 1993), and recent evidence further supports this concept (Spacek and Harris, 1997). Because BFA did not affect baseline responses or the number of synaptic AMPA receptors while completely blocking NMDA-induced modifications, the scenario presented in Figure $7 A$ would appear to be more likely than the one in Figure $7 B$. However, our results differ from those obtained by Matthies et al. (1999). Although these authors found that BFA inhibited tetanus-induced LTP, they did observe a decrease in baseline responses after BFA perfusion in hippocampal slices. Therefore, more work remains to be done to determine the exact relationship between the secretory pathway and the exocytic processes in glutamatergic terminals. In any event, it does appear more and more likely that the keys to understanding molecular mechanisms of synaptic plasticity at excitatory synapses lie in the understanding of the exocytosis and endocytosis pathways for the AMPA receptors.

\section{REFERENCES}

Ambros-Ingerson J, Lynch G (1993) Channel gating kinetics and synaptic efficacy: a hypothesis for expression of long-term potentiation. Proc Natl Acad Sci USA 90:7903-7907.

Ambros-Ingerson J, Xiao P, Larson J, Lynch G (1993) Waveform analysis suggests that LTP alters the kinetics of synaptic receptor channels. Brain Res 620:237-244.

Baude A, Molnar E, Latawiec D, McIlhinney RA, Somogyi P (1994) Synaptic and nonsynaptic localization of the GluR1 subunit of the AMPA-type excitatory amino acid receptor in the rat cerebellum. J Neurosci 14:2830-2843.

Baude A, Nusser Z, Molnar E, McIlhinney RA, Somogyi P (1995) High-resolution immunogold localization of AMPA type glutamate receptor subunits at synaptic and non-synaptic sites in rat hippocampus. Neuroscience 69:1031-1055.

Bi X, Standley S, Baudry M (1998) Posttranslational regulation of ionotropic glutamate receptors and synaptic plasticity. Int Rev Neurobiol 42:227-284.

Bliss TV, Lomo T (1973) Long-lasting potentiation of synaptic transmission in the dentate area of the anaesthetized rabbit following stimulation of the perforant path. J Physiol (Lond) 232:331-356.

Blitzer RD, Connor JH, Brown GP, Wong T, Shenolikar S, Iyengar R, Landau EM (1998) Gating of CaMKII by cAMP-regulated protein phosphatase activity during LTP. Science 280:1940-1942.

Carroll RC, Beattie EC, Xia H, Luscher C, Altschuler Y, Nicoll RA, Malenka RC, von Zastrow M (1999) Dynamin-dependent endocytosis of ionotropic glutamate receptors. Proc Natl Acad Sci USA 96:14112-14117.

del Cerro S, Larson J, Oliver MW, Lynch G (1990) Development of hippocampal long-term potentiation is reduced by recently introduced calpain inhibitors. Brain Res 530:91-95.

Denny JB, Polan-Curtain J, Ghuman A, Wayner MJ, Armstrong DL (1990) Calpain inhibitors block long-term potentiation. Brain Res 534:317-320

Engert F, Bonhoeffer T (1999) Dendritic spine changes associated with hippocampal long-term synaptic plasticity. Nature 399:66-70.

Hall RA, Hansen A, Andersen PH, Soderling TR (1997) Surface expression of the AMPA receptor subunits GluR1, GluR2, and GluR4 in stably transfected baby hamster kidney cells. J Neurochem 68:625-630.

Harris KM, Stevens JK (1988) Dendritic spines of rat cerebellar Purkinje cells: serial electron microscopy with reference to their biophysical characteristics. J Neurosci 8:4455-4469.

Hayashi Y, Shi SH, Esteban JA, Piccini A, Poncer JC, Malinow R (2000) Driving AMPA receptors into synapses by LTP and CaMKII: requirement for GluR1 and PDZ domain interaction. Science 287:2262-2267.

Henley JM (1995) Subcellular localization and molecular pharmacology of distinct populations of $\left[{ }^{3} \mathrm{H}\right]$-AMPA binding sites in rat hippocampus. Br J Pharmacol 115:295-301.

Isaac JT, Nicoll RA, Malenka RC (1995) Evidence for silent synapses: implications for the expression of LTP. Neuron 15:427-434.

Isaac JT, Nicoll RA, Malenka RC (1999) Silent glutamatergic synapses in the mammalian brain. Can J Physiol Pharmacol 77:735-737.
Isaac JT, Oliet SH, Hjelmstad GO, Nicoll RA, Malenka RC (1996) Expression mechanisms of long-term potentiation in the hippocampus. J Physiol (Paris) 90:299-303.

Kauer JA, Malenka RC, Nicoll RA (1988) NMDA application potentiates synaptic transmission in the hippocampus. Nature 334:250-252.

Klausner RD, Donaldson JG, Lippincott-Schwartz J (1992) Brefeldin A: insights into the control of membrane traffic and organelle structure. J Cell Biol 116:1071-1080.

Kolta A, Lynch G, Ambros-Ingerson J (1998) Effects of aniracetam after LTP induction are suggestive of interactions on the kinetics of the AMPA receptor channel. Brain Res 788:269-286.

Lee HK, Kameyama K, Huganir RL, Bear MF (1998) NMDA induces long-term synaptic depression and dephosphorylation of the GluR1 subunit of AMPA receptors in hippocampus. Neuron 21:1151-1162.

Liao D, Hessler NA, Malinow R (1995) Activation of postsynaptically silent synapses during pairing-induced LTP in CA1 region of hippocampal slice. Nature 375:400-404.

Lledo PM, Hjelmstad GO, Mukherji S, Soderling TR, Malenka RC, Nicoll RA (1995) Calcium/calmodulin-dependent kinase II and longterm potentiation enhance synaptic transmission by the same mechanism. Proc Natl Acad Sci USA 92:11175-11179.

Lledo PM, Zhang X, Sudhof TC, Malenka RC, Nicoll RA (1998) Postsynaptic membrane fusion and long-term potentiation. Science 279:399-403.

Luscher C, Xia H, Beattie EC, Carroll RC, von Zastrow M, Malenka RC, Nicoll RA (1999) Role of AMPA receptor cycling in synaptic transmission and plasticity. Neuron 24:649-658.

Luscher C, Nicoll RA, Malenka RC, Muller D (2000) Synaptic plasticity and dynamic modulation of the postsynaptic membrane. Nat Neurosci 3:545-550.

Lynch G, Baudry M (1984) The biochemistry of memory: a new and specific hypothesis. Science 224:1057-1063.

Maletic-Savatic M, Malinow R (1998) Calcium-evoked dendritic exocytosis in cultured hippocampal neurons. I. trans-Golgi network-derived organelles undergo regulated exocytosis. J Neurosci 18:6803-6813.

Maletic-Savatic M, Koothan T, Malinow R (1998) Calcium-evoked dendritic exocytosis in cultured hippocampal neurons. II. Mediation by calcium/calmodulin-dependent protein kinase II. J Neurosci 18:6814-6821.

Maletic-Savatic M, Malinow R, Svoboda K (1999) Rapid dendritic morphogenesis in CA1 hippocampal dendrites induced by synaptic activity. Science 283:1923-1927.

Malinow R, Schulman H, Tsien RW (1989) Inhibition of postsynaptic PKC or CaMKII blocks induction but not expression of LTP. Science 245:862-866.

Malinow R, Mainen ZF, Hayashi Y (2000) LTP mechanisms: from silence to four-lane traffic. Curr Opin Neurobiol 10:352-357.

Man YH, Lin JW, Ju WH, Ahmadian G, Liu L, Becker LE, Sheng M, Wang YT (2000) Regulation of AMPA receptor-mediated synaptic transmission by clathrin-dependent receptor internalization. Neuron 25:649-662.

Maren S, Tocco G, Standley S, Baudry M, Thompson RF (1993) Postsynaptic factors in the expression of long-term potentiation (LTP): increased glutamate receptor binding following LTP induction in vivo. Proc Natl Acad Sci USA 90:9654-9658.

Martone ME, Zhang Y, Simpliciano VM, Carragher BO, Ellisman MH (1993) Three-dimensional visualization of the smooth endoplasmic reticulum in Purkinje cell dendrites. J Neurosci 13:4636-4646.

Matthies Jr H, Kretlow J, Matthies H, Smalla KH, Staak S, Krug M (1999) Glycosylation of proteins during a critical time window is necessary for the maintenance of long-term potentiation in the hippocampal CA1 region. Neuroscience 91:175-183.

Misumi Y, Miki K, Takatsuki A, Tamura G, Ikehara Y (1986) Novel blockade by brefeldin A of intracellular transport of secretory proteins in cultured rat hepatocytes. J Biol Chem 261:11398-11403.

Musleh W, Bi X, Tocco G, Yaghoubi S, Baudry M (1997) Glycineinduced long-term potentiation is associated with structural and functional modifications of $\alpha$-amino-3-hydroxyl-5-methyl-4isoxazolepropionic acid receptors. Proc Natl Acad Sci USA 94:9451-9456.

Noel J, Ralph GS, Pickard L, Williams J, Molnar E, Uney JB, Collingridge GL, Henley JM (1999) Surface expression of AMPA receptors in hippocampal neurons is regulated by an NSF-dependent mechanism. Neuron 23:365-376.

Oda K, Hirose S, Takami N, Misumi Y, Takatsuki A, Ikehara Y (1987) Brefeldin A arrests the intracellular transport of a precursor of complement C3 before its conversion site in rat hepatocytes. FEBS Lett 214:135-138.

Pettit DL, Perlman S, Malinow R (1994) Potentiated transmission and prevention of further LTP by increased CaMKII activity in postsynaptic hippocampal slice neurons. Science 266:1881-1885.

Rubio ME, Wenthold RJ (1999) Differential distribution of intracellular glutamate receptors in dendrites. J Neurosci 19:5549-5562.

Shahi K, Marvizon JC, Baudry M (1993) High concentrations of glycine 
induce long-lasting changes in synaptic efficacy in rat hippocampal slices. Neurosci Lett 149:185-188.

Shi SH, Hayashi Y, Petralia RS, Zaman SH, Wenthold RJ, Svoboda K, Malinow R (1999) Rapid spine delivery and redistribution of AMPA receptors after synaptic NMDA receptor activation. Science 284:1811-1816.

Song I, Kamboj S, Xia J, Dong H, Liao D, Huganir RL (1998) Interaction of the $N$-ethylmaleimide-sensitive factor with AMPA receptors. Neuron 21:393-400.

Spacek J, Harris KM (1997) Three-dimensional organization of smooth endoplasmic reticulum in hippocampal CA1 dendrites and dendritic spines of the immature and mature rat. J Neurosci 17:190-203.

Standley S, Bi X, Baudry M (1996) Glutamate receptor regulation and synaptic plasticity. In: Long-term potentiation, Vol III (Baudry M, Davis JL, eds), pp 17-40. Cambridge, MA: MIT.

Standley S, Tocco G, Wagle N, Baudry M (1998) High- and low-affinity $\alpha$ - $\left[{ }^{3} \mathrm{H}\right]$ amino-3-hydroxy-5-methylisoxazole-4-propionic

acid $\left(\left[{ }^{3} \mathrm{H}\right] \mathrm{AMPA}\right)$ binding sites represent immature and mature forms of AMPA receptors and are composed of differentially glycosylated subunits. J Neurochem 70:2434-2445.
Staubli U, Ambros-Ingerson J, Lynch G (1992) Receptor changes and LTP: an analysis using aniracetam, a drug that reversibly modifies glutamate (AMPA) receptors. Hippocampus 2:49-57.

Thibault O, Joly M, Muller D, Schottler F, Dudek S, Lynch G (1989) Long-lasting physiological effects of bath applied $N$-methyl-D-aspartate. Brain Res 476:170-173.

Toni N, Buchs PA, Nikonenko I, Bron CR, Muller D (1999) LTP promotes formation of multiple spine synapses between a single axon terminal and a dendrite. Nature 402:421-425.

Turrigiano GG (2000) AMPA receptors unbound: membrane cycling and synaptic plasticity. Neuron 26:5-8.

Vanderklish P, Saido TC, Gall C, Arai A, Lynch G (1995) Proteolysis of spectrin by calpain accompanies theta-burst stimulation in cultured hippocampal slices. Brain Res Mol Brain Res 32:25-35.

Wang YT, Linden DJ (2000) Expression of cerebellar long-term depression requires postsynaptic clathrin-mediated endocytosis. Neuron 25:635-647.

Xie X, Liaw JS, Baudry M, Berger TW (1997) Novel expression mechanism for synaptic potentiation: alignment of presynaptic release site and postsynaptic receptor. Proc Natl Acad Sci USA 94:6983-6988. 